\title{
Intensive culture of juvenile and adult Eurasian perch ( $P$. fluviatilis): effect of major biotic and abiotic factors on growth
}

\author{
By C. Mélard ${ }^{1}$, P. Kestemont ${ }^{2}$ and J. C. Grignard ${ }^{1}$ \\ ${ }^{1}$ Laboratory of Fish Demography and Aquaculture, University of Liège, 10 Chemin de la Justice B-4500 Tihange, Belgium; ${ }^{2}$ Unité \\ d'Ecologie des Eaux Douces, Facultés Universitaires N.D. de la Paix, 61, Rue de Bruxelles, B-5000 Namur, Belgium
}

\section{Summary}

Recent developments in Eurasian perch (Perca fluviatilis) larval rearing and weaning techniques allow large-scale intensive rearing tests, both with juveniles and adults. This review presents the results of experiments conducted in a commercial scale production environment $\left(0.5-1.6 \mathrm{~m}^{3}\right.$ flow-through tanks) and focuses on the most relevant factors influencing growth and production in intensive rearing systems. Combined effects of food ration and temperature showed that the maximum growth rates $\left(0.06-1.80 \mathrm{~g}_{\text {fish }}{ }^{-1}\right.$ day $^{-1}$ for $1-300 \mathrm{~g}$ fish) were observed at $23^{\circ} \mathrm{C}$. The thermal range for intensive rearing of perch extends at least down to $11^{\circ} \mathrm{C}$ (growth rate equivalent to $29 \%$ of that observed at $\left.23^{\circ} \mathrm{C}\right)$. The maximum daily food ration $(9-4.5 \%$ lipid; $57-44 \%$ crude protein) at $23^{\circ} \mathrm{C}$ resulted in feed conversion rates from 1.1 to 2.0 in fish ranging from 1 to $150 \mathrm{~g}$ and was modelled as follows $\left(R^{2}=0.89\right): \mathrm{R}_{\max }\left(\%\right.$ day $\left.^{-1}\right)=7.60 \mathrm{w}$ (weight, g) $)^{-0.31}$. Juvenile $(1-15 \mathrm{~g})$ perch reared at 10000 fish $\mathrm{m}^{-3}$ showed a growth rate of $0.2 \mathrm{~g} \mathrm{fish}^{-1}$ day $^{-1}$, thus $67 \%$ higher than at $400 \mathrm{fish} \mathrm{m}^{-3}$. In the most intensive rearing trials $\left(124 \mathrm{~kg} \mathrm{~m}^{-3}\right)$, the maximum production rate observed was $2.6 \mathrm{~kg} \mathrm{~m}^{-3} \mathrm{day}^{-1}$.

Growth heterogeneity constitutes a major constraint in perch culture. Size grading experiments resulted in the emergence of fast-growing fish in each sorted group. In addition, the sorting process caused the productivity to be slightly lower $(5-6 \%)$ than in non-sorted populations of the same origin and body weight. Mass mortality may take place at any stage of perch rearing within the $1-200 \mathrm{~g}$ body weight range. In general, an overall $50 \%$ survival rate was recorded after 14 months. Parasites, bacteria and fungi were the most frequently encountered causes of mortality. The occurrence and impact of diseases were largely reduced in recirculating systems where the survival rate is $70 \%$ higher than the values observed in flow-through rearing systems. In intensive rearing systems at $23^{\circ} \mathrm{C}$ and at maximum stocking biomass of $50 \mathrm{~kg} \mathrm{~m}^{-3}, 44$-day- old weaned perch juveniles (ranging from 0.5 to $1 \mathrm{~g}$ initial body weight) reached an average body weight of $130-150 \mathrm{~g}$ after 1 year of rearing. Still, this marketable size was reached about 3 months earlier by fast growing individuals within the population.

The intensive culture of perch at a constant $23^{\circ} \mathrm{C}$ water temperature allowed much higher growth rates than usually observed in conventional, extensive systems under natural thermal regimes. Constant temperatures also inhibited the sexual maturation in females. Further improvements in growth and productivity in intensive perch rearing will closely rely on techniques such as the selection of fast-growing strains, monosex female or sterile triploïd fish production.

\section{Introduction}

During the last 5 years, there has been a growing interest in Eurasian perch ( $P$. fluviatilis) culture (Fontaine et al. 1993; Mélard et al. 1994; Tamazouzt et al. 1994) to cope with the demand of an annual European market of about 5-10 thousand tons, mainly consisting of $120-140 \mathrm{~g}$ fish (Fontaine et al. 1993). By contrast with yellow perch (Perca flavescens), (Heidinger and Kayes 1986), the intensive rearing of the Eurasian perch has received little attention (Fontaine et al. 1993; Tamazouzt et al. 1993). At present, most of the marketable stocks originate from extensive polyculture in ponds or lake reservoirs, where perch usually represent from 2 to $5 \%$ of the total yield (Huet 1970; Tamazouzt et al. 1993; Setälä et al. 1995). Recent developments in larval rearing and weaning techniques (Mélard and Kestemont 1994; Mélard et al. 1994; Kestemont et al. 1995; Mélard et al. 1996) allow the production of weaned juveniles to continue with large scale intensive grow-out experiments, both with juveniles and adults (Mélard et al. 1995a, b). This paper summarizes the current knowledge on intensive perch culture and introduces the results of our latest culture trials with juvenile and adult Eurasian perch intensively reared under 'industrial-like production conditions' (flow-through tanks, warm water effluents, high stocking density). It focuses on rearing parameters which are usually the most relevant for territorial species (Arctic charr, Salvelinus alpinus): relationships between fish growth, body weight, food ration and rearing temperature, followed by the effects of stocking density on fish growth and size heterogeneity (e.g., Jobling et al. 1993).

\section{Rearing conditions and techniques}

Juvenile perch used in the experiments were produced from eyed stage eggs reared at a $23^{\circ} \mathrm{C}$ in a semi-intensive larval rearing system, consisting of 'green water' tanks. Larvae were gradually trained to accept formulated feed by replacing Artemia nauplii with a dry diet (Mélard et al. 1994, 1996) and averaged $0.5-1.0 \mathrm{~g}$ at the end of a 44-day rearing period.

The experiments with juvenile and adult perch were carried out in $0.5 \mathrm{~m}^{3}$ ( $<15 \mathrm{~g}$ fish) then in $1.6 \mathrm{~m}^{3}$ ( $>15 \mathrm{~g}$ fish) flowthrough tanks filled with water from the River Meuse which had been used as cooling water for a nuclear power plant. Water temperature in nutritional studies ranged from 11 to $27^{\circ} \mathrm{C}$. In all trials, oxygen was maintained at the same level and above $6.0 \mathrm{mg} \mathrm{O}_{2} \mathrm{l}^{-1}$, by adjusting water renewal rate to stocking biomass. Commercial trout dry feeds (from 9 to $4.5 \%$ lipid and 57 to $44 \%$ crude protein contents with increasing fish weight), 
were distributed by automatic feeders over a 12 -h period (continuous diurnal feeding). Food rations were calculated according to established relationships between optimal and maximal rations and fish weight (see effect of food ration). The number and total biomass of fish in each experiment were measured biweekly. Individual weights were determined by weighing 100 fish individually (to $0.1 \mathrm{~g}$ then to the nearest $\mathrm{g}$ ). Each experiment was duplicated. Fish growth and production were studied until fish averaged $300 \mathrm{~g}$, far above the minimal size for marketing (120-140 g, Tamazouzt et al. 1994).

Feeding experiments were carried out for six body weight categories (mean body weight of 3, 8, 20, 100, 150 and $300 \mathrm{~g}$ ) of perch reared at $23^{\circ} \mathrm{C}$. Final stocking biomasses ranged from 24 to $35 \mathrm{~kg} \mathrm{~m}^{-3}$, depending on fish body weight. For each body weight category, six different food rations were evaluated. Fish growth (biomass and sample of 100 individual weights) was measured after 13 feeding days. Maintenance, optimum and maximum food rations were determined from growth to ration plots, accordingly with the model of Brett et al. (1969). Similar experiments were conducted at three alternative thermal regimes $\left(11,20\right.$ and $\left.27^{\circ} \mathrm{C}\right)$ to determine the relationship between rearing temperature and growth performance.

The effect of stocking density on fish growth was assessed in $0.5 \mathrm{~m}^{-3}$ tanks for $1-15 \mathrm{~g}$ fish (74-day experiment) then in $1.6 \mathrm{~m}^{3}$ tanks for $15-50 \mathrm{~g}$ fish (103-day experiment). The final stocking biomasses for the two size categories ranged from 3 to $124 \mathrm{~kg}$ $\mathrm{m}^{-3}$ and from 15 to $79 \mathrm{~kg} \mathrm{~m}^{-3}$, respectively. The effect of a single size-grading (three non-overlapping categories, using size-sorting grids) on fish growth was carried out in the latter experimental conditions. The final stocking biomass ranged from 31 to $34 \mathrm{~kg} \mathrm{~m}^{-3}$, depending on the size category (see Mélard et al. 1995b; Mélard and Kestemont 1995).

\section{Effect of water temperature and body weight}

Combined growth-food ratio-temperature experiments showed that maximum growth rates $\left(0.06-1.80 \mathrm{~g} \mathrm{fish}^{-1} \mathrm{day}^{-1}\right.$ for $3-300 \mathrm{~g}$ fish) were observed at $23^{\circ} \mathrm{C}$. Rearing at higher $\left(27^{\circ} \mathrm{C}\right)$ or lower temperatures $\left(11-20^{\circ} \mathrm{C}\right)$ resulted in lower growth rates, i.e., the growth of $15 \mathrm{~g}$ fish at $27^{\circ} \mathrm{C}$ was $12 \%$ lower than at $23^{\circ} \mathrm{C}$. Similarly, $100 \mathrm{~g}$ body weight perch reared at $20^{\circ} \mathrm{C}$ showed a $20 \%$ lower growth compared to fish of the same body weight at $23^{\circ} \mathrm{C}$ (Mélard and Kestemont 1995; Fig. 1). Therefore, $23^{\circ} \mathrm{C}$ will be considered the standard production temperature henceforth. At $23^{\circ} \mathrm{C}$, perch reaching the minimum size for marketing show a specific growth rate $\left(\mathrm{SGR}=(\mathrm{LnW} 2-\mathrm{LnW} 1) \mathrm{t}^{-1}\right)$ around $0.86 \%$ day $^{-1}\left(1.2 \mathrm{~g} \mathrm{day}^{-1}\right.$ in $140 \mathrm{~g}$ fish). However, water temperature for intensive rearing of perch extends at least to $11^{\circ} \mathrm{C}$, with a relative growth rate at $11^{\circ} \mathrm{C}$ equivalent to $29 \%$ of that observed at $23^{\circ} \mathrm{C}$ (Mélard and Kestemont 1995).

\section{Effect of food ration, protein level and feeding frequency}

The maintenance $\left(R_{\text {maint }}\right)$, optimum $\left(R_{\text {opt }}\right)$ and maximum $\left(R_{\max }\right)$ daily food ration of 3-300 g perch reared at $23^{\circ} \mathrm{C}$ were modelled as follows (Fig. 2):

$\mathrm{R}_{\text {maint }}=1.09 \mathrm{w}^{-0.23} \quad R^{2}=0.97 ; F=149.6, \mathrm{P}<0.05$

$\mathrm{R}_{\text {opt }}=3.30 \mathrm{w}^{-0.24} \quad R^{2}=0.85 ; F=23.5, \mathrm{P}<0.05$

$\mathrm{R}_{\max }=7.60 \mathrm{w}^{-0.31} \quad R^{2}=0.89 ; F=33.3 ; \mathrm{P}<0.05$

where $\mathrm{w}=$ fish body weight $(\mathrm{g})$ and $\mathrm{R}=$ daily ration $(\%$ body weight day $\left.{ }^{-1}\right)$.

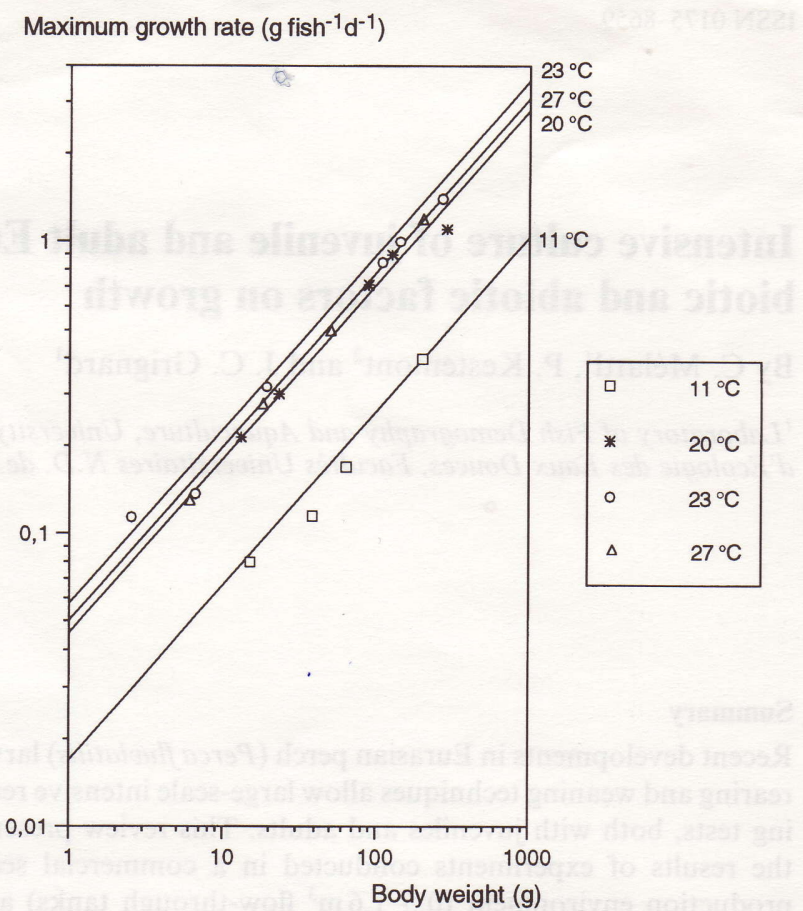

Fig. 1. Effect of temperature and fish body weight on maximal daily growth rate of the Eurasian perch in intensive culture. Stocking biomass: $24-35 \mathrm{~kg} \mathrm{~m}^{-3}$ (after Mélard and Kestemont 1995)

The maximum daily ration provided feed conversion ratios (FCR) from 1.1 to 2.0 in fish ranging from 1 to $150 \mathrm{~g}$, and FCR up to 3.0 in $300 \mathrm{~g}$ fish. The corresponding FCR for $\mathrm{R}_{\text {opt }}$ were 1.0, 1.7 and 2.0, respectively (Mélard and Kestemont 1995; Fig. 3). The relationship between SGR and food protein content indicated that the optimum crude protein content was consistent throughout the 3-20 g weight range, averaging $42-43 \%$ (Fiogbé et al. 1996; Fig. 4).

Preliminary trials on feeding frequency (daily ration of $2 \%$ body weight distributed in 1, 3 or 6 meals) with $30 \mathrm{~g}$ perch demonstrated highest growth rates when fish were fed 3 times a day. Under a more restricted food supply (i.e., daily ration of $1 \%$ body weight), a feeding frequency of 6 meals day ${ }^{-1}$ produced the highest growth rate but increased the size heterogeneity of the fish population (Kestemont and Mélard 1996).

\section{Effect of stocking density}

Increased stocking density from 400 to 10000 fish $\mathrm{m}^{-3}$ resulted in a $67 \%$ increase in growth rate for juvenile fish (initial body weight: $1 \mathrm{~g}$ ) reared at $23^{\circ} \mathrm{C}$ during 74 days (growth rate was $0.2 \mathrm{~g} \mathrm{fish}^{-1}$ day $^{-1}$ at the highest stocking density and $0.12 \mathrm{~g} \mathrm{fish}^{-1}$ day $^{-1}$ at the lowest stocking density; Fig. 5). This seems to originate from a density-dependent inhibition of territorial and agonistic tendencies that potentially limit access to food. This hypothesis is supported by the growth heterogeneity observed at each stocking density, since coefficients of variation of fish body weight at the end of a 74-day rearing period decreased from 98.4-57.9\% with increasing stocking density (Mélard et al. 1996; Fig. 5). Survival was not dependent on stocking density and averaged $85 \%$. In the most intensive rearing trials $(124 \mathrm{~kg}$ $\mathrm{m}^{-3}$ ), the maximum production rate observed was $2.6 \mathrm{~kg} \mathrm{~m}^{-3}$ day $^{-1}$. This positive relationship between density and growth was valid until fish reached $15-20 \mathrm{~g}$ body weight. In larger individuals, growth rate decreased with increasing stocking densities. For example, the growth of perch at the end of 103 days 
Daily food rations ( $\%$ body weight $d^{-1}$ )

Fig. 2. Relationships between daily food rations (maximum, optimum and maintenance) and fish body weight of Eurasian perch intensively cultured at $23^{\circ} \mathrm{C}$. Stocking biomass: $24-35 \mathrm{~kg} \mathrm{~m}^{-3}$ (after Mélard and Kestemont 1995)

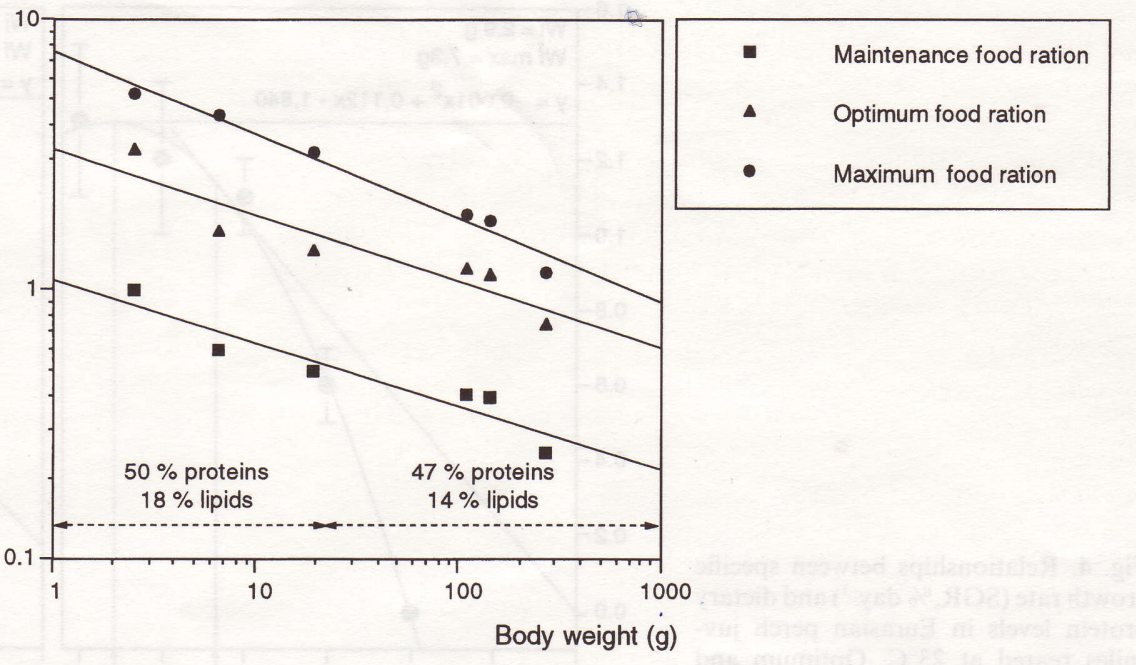

\section{Food conversion ratio}

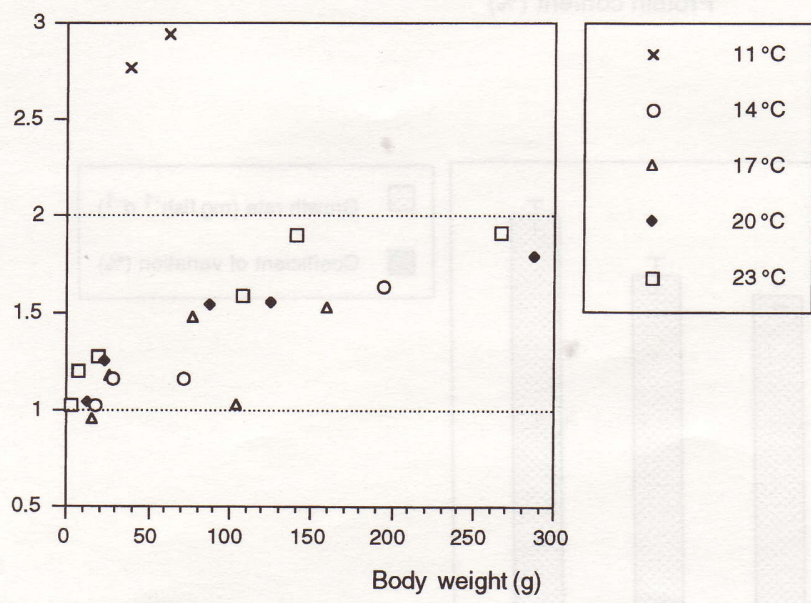

Fig. 3. Effect of fish body weight and temperature on food conversion ratio in intensively cultured Eurasian perch fed at $R_{\text {opt }}$. Stocking biomass: $24-35 \mathrm{~kg} \mathrm{~m}^{-3}$ (after Mélard and Kestemont 1995)

for fish reared at 2080 individuals $\mathrm{m}^{-3}$, was $20 \%$ lower than for fish at reared at 308 individuals $\mathrm{m}^{-3}$ (mean final weight and biomass, $40.1 \mathrm{~g}$ and $79 \mathrm{~kg} \mathrm{~m}^{-3}, 50.4 \mathrm{~g}$ and $15 \mathrm{~kg} \mathrm{~m}^{-3}$, respectively). Similarly, the effect of stocking density on growth heterogeneity was not significant $(P<0.05)$ at this size. The maximum production rate $\left(0.8 \mathrm{~kg} \mathrm{~m}^{-3}\right.$ day $\left.^{-1}\right)$ was achieved at a $60 \mathrm{~kg} \mathrm{~m}^{-3}$ stocking biomass (Mélard and Kestemont 1994).

\section{Effect of size grading}

A major feature in perch culture is growth heterogeneity, where body weight can range from 7 to $89 \mathrm{~g}$ for 7 -month-old perch averaging $25.9 \mathrm{~g}$. Sorting a population into three non-overlapping weight groups resulted in similar mean specific growth rates, where fast-growing fish emerged within each group (Mélard et al. 1995b; Fig. 6). For fish cultured 200 days after size grading, the increase of heterogeneity was so high that the weight distributions of each group overlapped by more than $60 \%$. Size grading probably suppressed some form of growth inhibition resulting from territoriality or social hierarchy. As a corollary, it is suggested that growth heterogeneity does not originate exclusively from sexual growth dimorphism (female growth averaging 1.5-1.7 times male growth; Mélard \& Kestemont 1995) or from other genetic traits but also from social behaviour (Craig 1987; Mélard et al. 1995b). Although sizegrading contributes to the emergence of fast growing fish, it does not increase productivity of the rearing system. For instance, non-sorted populations had a growth rate 5-6\% higher than in size-graded populations from the same origin and body weight (Mélard and Kestemont 1995; Fig. 7).

\section{Survival and growth rates}

Mass mortality may occur throughout perch rearing within the 1-200 g body weight range and resulted in an overall $50 \%$ survival rate after 14 months. Abiotic factors, including direct or indirect mortality resulting from handling, accounted for only a small part of overall mortality. Parasites, bacteria and fungi were the most frequently encountered causes (Grignard et al. 1995). Pathologies were far less frequent in recirculating systems where the survival rate was about $70 \%$ higher than in flow-through rearing systems (Kestemont and Mélard 1996). In intensive rearing systems at a $23^{\circ} \mathrm{C}$ and at maximum stocking biomass of $50 \mathrm{~kg} \mathrm{~m}^{-3}$, juveniles weaned after 44 days reached an average body weight of $130-150 \mathrm{~g}$ after 1 year of rearing. Market size was reached about 3 months earlier by fast-growing individuals within the population (Fig. 8), thus allowing a better share of production over the annual cycle, depending on market demand. As mentioned earlier, this growth heterogeneity may result from intrinsic genetic features, including sexual dimorphism (slow growth of males), as well as from a social growth inhibition.

\section{Conclusions}

Intensive culture of Eurasian perch at a constant water temperature of $23^{\circ} \mathrm{C}$ produced much higher growth rates than usually obtained in conventional extensive systems in ponds under natural thermal regimes, where $0^{+}$perch average $5-10 \mathrm{~g}$ of body weight before overwintering (Huet 1970; Craig 1987). Similarly, yellow perch reared in outdoor facilities do not reach a market size before 2 years of rearing (Brown and Dabrowski 1995). In our experiments (high stocking biomass from 30 to $60 \mathrm{~kg} \mathrm{~m}^{-3}$, balanced sex-ratio), the market size of $120-140 \mathrm{~g}$ was reached after 1 year by only half of the fish, of which $80 \%$ were 
Fig. 4. Relationships between specific growth rate $\left(\mathrm{SGR}, \%\right.$ day $\left.^{-1}\right)$ and dietary protein levels in Eurasian perch juveniles reared at $23^{\circ} \mathrm{C}$. Optimum and maximum protein levels have been calculated for perch of 2.9 and $15.8 \mathrm{~g}$ initial body weight (after Fiogbé et al. 1996)
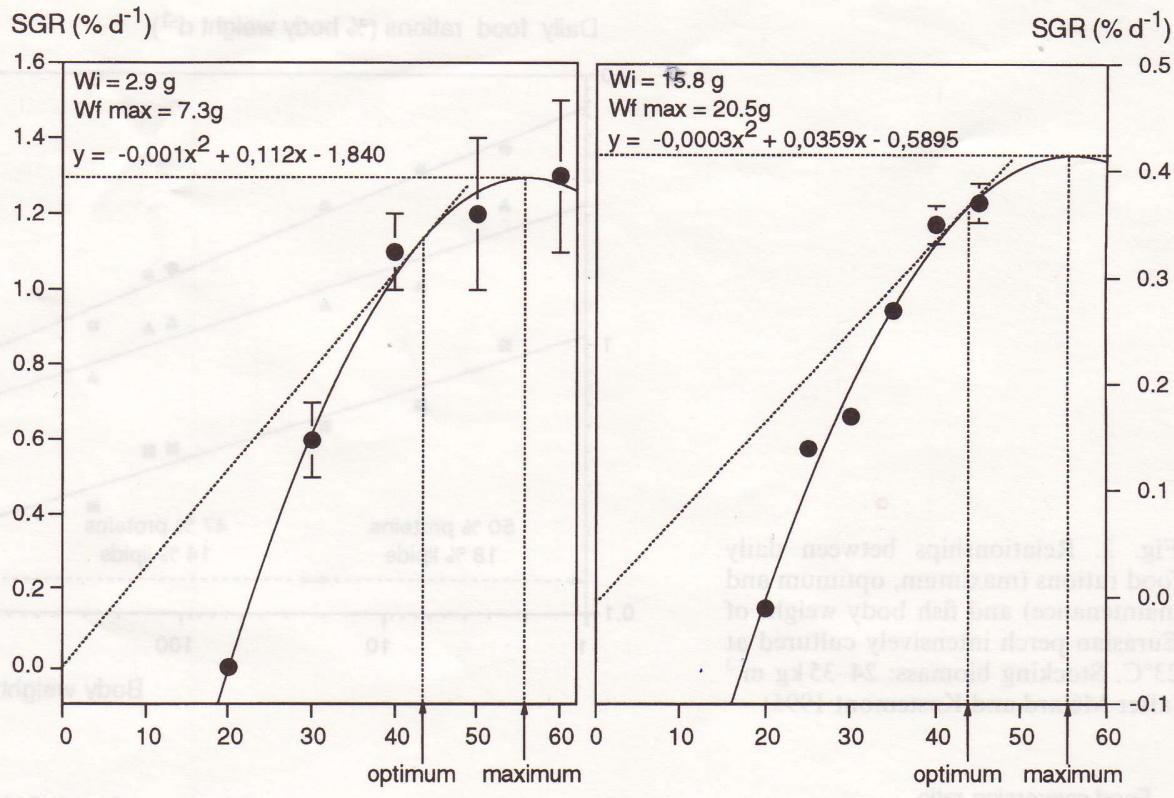

Protein content (\%)
Fig. 5. Effect of stocking density on the growth rate and heterogeneity in juvenile Eurasian perch (initial body weight: $1 \mathrm{~g}$ ) reared at $23^{\circ} \mathrm{C}$ for 74 days. Error bars refer to discrepancies between replicates (after Mélard et al. 1996)

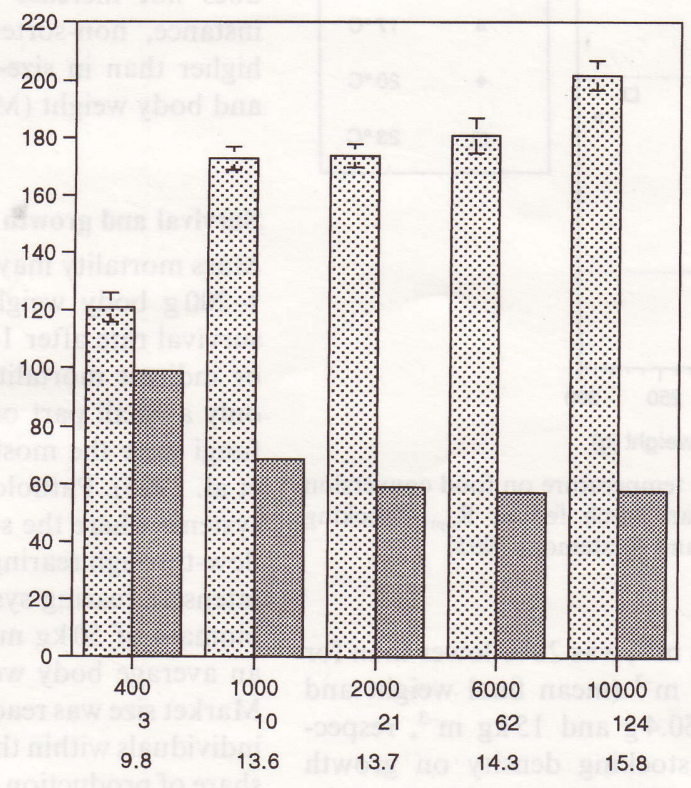

Initial stocking density (fish $\mathrm{m}^{-3}$ )
Final stocking biomass $\left(\mathrm{kg} \mathrm{m}^{-3}\right.$ )

Final body weight $(g)$ female individuals. This refers to fish starting from the eggs, with a food conversion ratio (FCR) lower than 1.5 in fish fed at optimal ration. These results are consistent with those documented by Brown and Dabrowski (1995) for P. flavescens reared for 9-15 months in indoor facilities at constant temperatures. Independent of high temperature and free access to food resources, this growth rate higher than normal can be accounted for by the inhibition of sexual maturation of females under constant temperatures above $18^{\circ} \mathrm{C}$, whilst females normally show gonadosomatic indices as high as $20 \%$ at the time of spawning (Thorpe 1977; Craig 1987).

From our experiments at different stocking densites, it is obvious that intensive rearing positively trades off a slight growth deficit by a much higher productivity. However, inten- sive rearing does not grant a survival rate higher than $50 \%$ starting from weaned $1 \mathrm{~g}$ juveniles and favours growth heterogeneity. Despite some individual fish (10-15\%) showing a high growth potential, the Eurasian perch is generally a slow-growing fish even in optimal rearing conditions (mean body weight: $120 \mathrm{~g}$ in 1 year). Further improvements in intensive rearing systems should thus focus on these two parameters. Survival rates could be increased by: a) improving the quality of weaned juveniles and their resistance to handling stress and pathologies, which can be achieved through two complementary axes; b) improving the quality of eggs and larvae by giving the broodstock an appropriate diet (Abi-Ayad et al. 1996) and using more adapted larval rearing technology such as rearing in 'green water' tanks (Brown et al. 1989; Lavens et al. 1994); c) using 

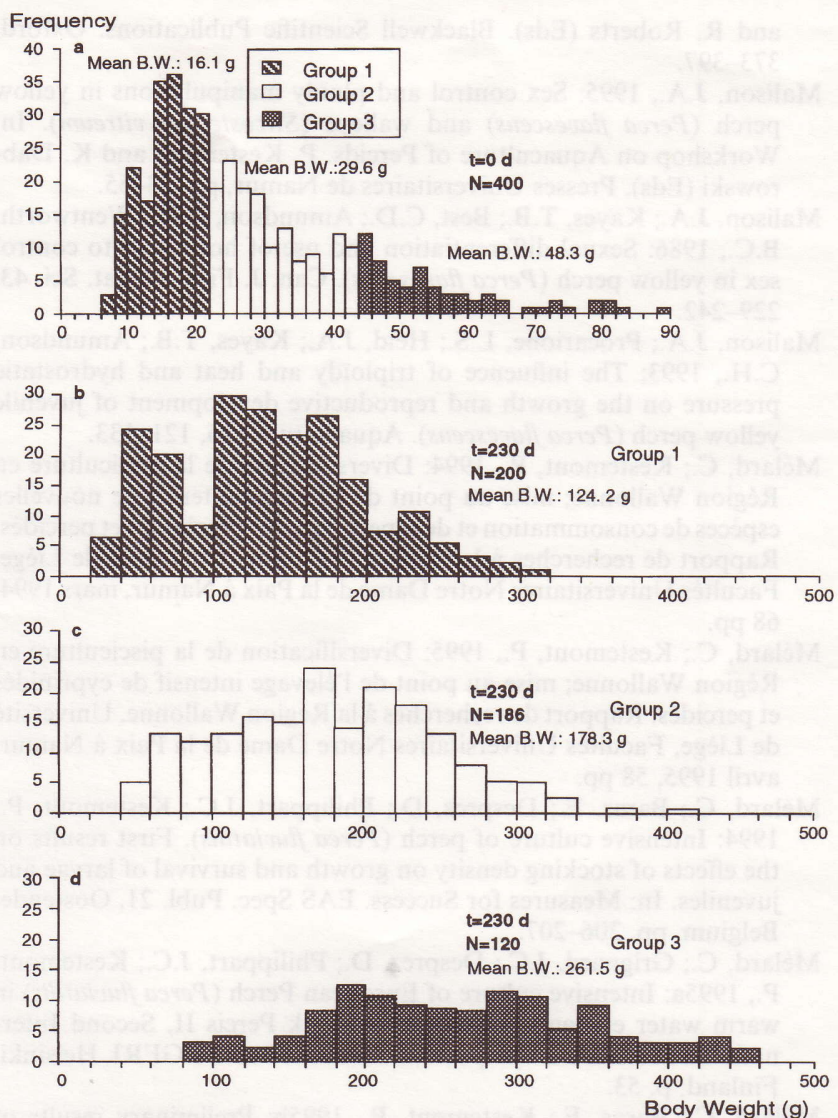

Fig. 6. Effect of initial grading of a population of cultured perch in three non-overlapping groups (a) on growth heterogeneity in intensively cultured Eurasian perch after 230 days of rearing at $22.2^{\circ} \mathrm{C}(\mathrm{b}, \mathrm{c}, \mathrm{d})$. Final stocking biomass: 31,34 and $31 \mathrm{~kg} \mathrm{~m}^{-3}$ (after Mélard et al. 1995b)

recirculating systems to minimize hazards from pathologies (Kestemont and Mélard 1996); tailoring the quality of the diet to the precise nutritional requirements of perch, essentially with respect to fatty acid content to minimize the risks of hepatic degeneration (Grignard et al. 1996) and lower resistance to pathologies. Higher growth rates and lower size heterogeneity could be achieved through the production of a monosex female population (Malison et al. 1986) or sterile triploïd fish (Malison et al. 1993; Malison, 1995). Similarly, future investigations on

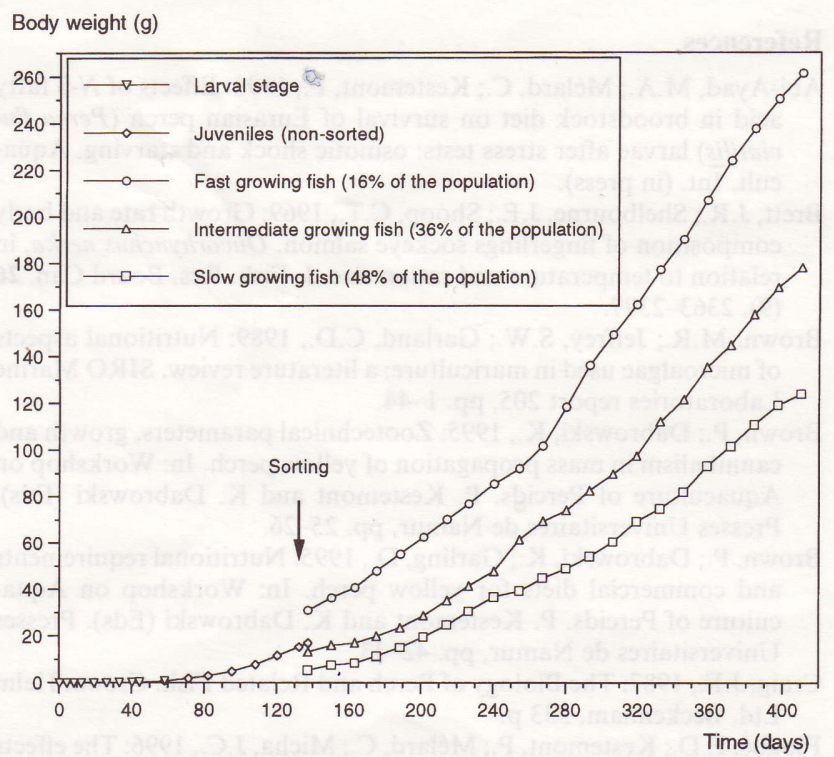

Fig. 8 Growth of Eurasian perch reared at $23^{\circ} \mathrm{C}$ in intensive culture conditions starting from the egg. Stocking biomass ranging from 25 to $100 \mathrm{~kg} \mathrm{~m}^{-3}$; (after Mélard and Kestemont 1994, 1995)

the accurate nutritional requirements of various life stages of the Eurasian perch with respect to a dietary protein or fatty acid composition, could allow better fish growth and FCR through the distribution of a tailored formulation (Brown et al. 1995; Fiogbé et al. 1996).

Finally, the selection of strains with high growth performances and high resistance to stress and pathologies will represent a considerable improvement in the development of intensive perch rearing in the forthcoming years.

\section{Acknowledgements}

This research was supported by the Walloon Government (Direction Générale des Ressources Naturelles et de l'Environnement, Belgium) and Electrabel S.A.
Fig. 7. Growth rate of non-sorted and size-graded populations of Eurasian perch reared at $23^{\circ} \mathrm{C}$ during a 70 -day period. Mean growth rate of sizegraded population calculated by weighing the mean growth rates of each sorted fraction by their relative frequency $(\%)$. Final stocking biomass: $29-33 \mathrm{~kg} \mathrm{~m}^{-3}$ (after Mélard and Kestemont 1995)

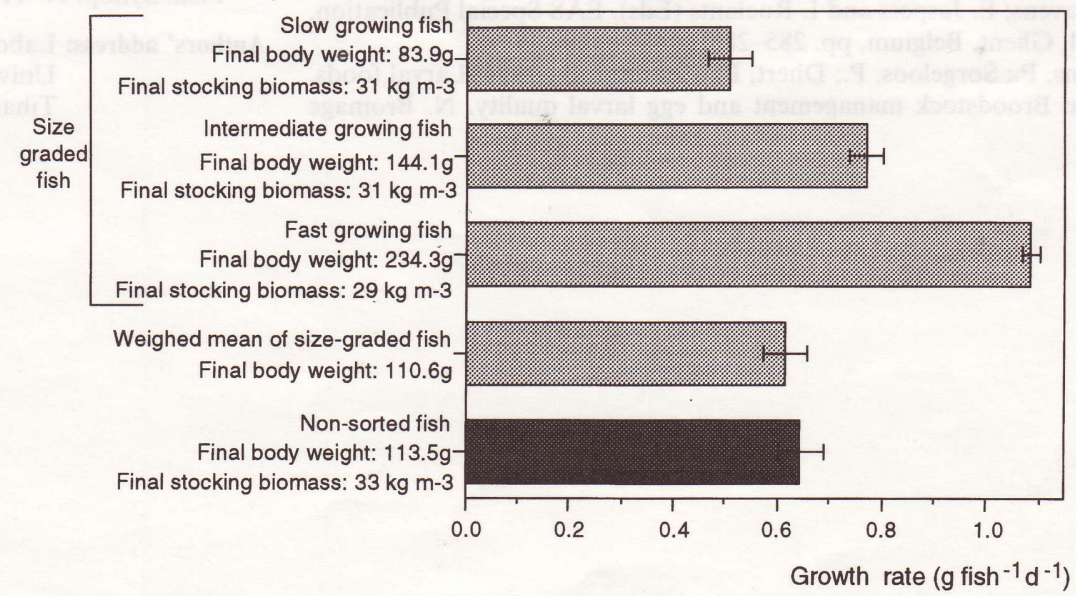




\section{References}

Abi-Ayad, M.A.; Mélard, C.; Kestemont, P., 1996: Effects of N-3 fatty acid in broodstock diet on survival of Eurasian perch (Perca fluviatilis) larvae after stress tests: osmotic shock and starving. Aquacult. Int. (in press)

Brett, J.R.; Shelbourne, J.E.; Shoop, C.T., 1969: Growth rate and body composition of fingerlings sockeye salmon, Oncorhynchus nerka, in relation to temperature and ration size. J. Fish. Res. Board Can. 26 (9), 2363-2397.

Brown, M.R.; Jeffrey, S.W.; Garland, C.D., 1989: Nutritional aspects of microalgae used in mariculture; a literature review. SIRO Marine Laboratories report 205, pp. 1-44.

Brown, P.; Dabrowski, K., 1995: Zootechnical parameters, growth and cannibalism in mass propagation of yellow perch. In: Workshop on Aquaculture of Percids. P. Kestemont and K. Dabrowski (Eds). Presses Universitaires de Namur, pp. 25-26.

Brown, P.; Dabrowski, K.; Garling, D., 1995: Nutritional requirements and commercial diets for yellow perch. In: Workshop on Aquaculture of Percids. P. Kestemont and K. Dabrowski (Eds). Presses Universitaires de Namur, pp. 42-43.

Craig, J.F., 1987: The Biology of Perch and Related Fish. Croom Helm Ltd, Beckenham, 333 p.

Fiogbé, E.D.; Kestemont, P.; Mélard, C.; Micha, J.C., 1996: The effects of dietary crude protein on growth of the Eurasian perch (Perca fluviatilis). Aquaculture, (in press).

Fontaine, P.; Tamazouzt, L.; Terver, D.; Georges, A., 1993: Actual state of production of perch: problems and prospects. 1. Mass rearing potentialities of the common perch under controlled conditions. In: Workshop on Aquaculture of Freshwater Species (except salmonids). P. Kestemont and R. Billard (Eds). EAS Spec. Publ., 20, Ghent, Belgium, pp. 46-48.

Grignard, J.C.; Mélard, C.; Kestemont, P., 1995: Pathology of perch (P. fluviatilis) in intensive culture system: A preliminary list of pathogenic agents. In: Workshop on Aquaculture of Percids. P. Kestemont and K. Dabrowski (Eds). Presses Universitaires de Namur, pp. 56-59.

Grignard, J.C.; Mélard, C.; Kestemont, P., 1996: A preliminary study of parasites and diseases of perch $(P$. fluviatilis $)$ in intensive culture system. J. Appl. Ichthyol. 12, 00-00.

Huet, M., 1970: Traité de pisciculture. Eds: edns Ch. De Wyngaert, Bruxelles, Belgium. 718 p.

Heidinger, J.G.; Kayes, T.B., 1986: Yellow perch. In: Culture of Nonsalmonid Freshwater Fishes. R.R. Stickney (Ed.). CRC Press, Boca Raton, FL., pp. 103-113.

Jobling, M.; Jorgensen, E.H.; Arnesen, A.M.; Ringo, E., 1993: Feeding, growth and environmental requirements of Arctic charr: a review of aquaculture potential. Aquacul. Int. 1, 20-46.

Kestemont, P.; Mélard, C., 1996: Mise au point et développement d'une technologie d'élevage intensif des Percidés en Région Wallonne. Rapport annuel no. 1. Ministère de la Région Wallonne, Université de Liège, Facultés Universitaires Notre Dame de la Paix à Namur, avril 1996, 74 p.

Kestemont, P.; Fiogbé, E.D.; Parfait, O.; Micha, J.C.; Mélard, C., 1995: Relationship between weaning size, growth, survival and cannibalism in the common perch larvae (Perca fluviatilis). Preliminary data. In: Larvi '95, Fish and Shellfish Larviculture Symposium. P. Lavens; E. Jaspers and I. Roelants (Eds). EAS Special Publication, 24, Ghent, Belgium, pp. 285-288.

Lavens, P.; Sorgeloos, P.; Dhert, P.; Devresse, B., 1994: Larval foods. In: Broodstock management and egg larval quality. N. Bromage and R. Roberts (Eds). Blackwell Scientific Publications. Oxford, 373-397.

Malison, J.A., 1995: Sex control and ploïdy manipulations in yellow perch (Perca flavescens) and walleye (Stizostedion vitreum). In: Workshop on Aquaculture of Percids. P. Kestemont and K. Dabrowski (Eds). Presses Universitaires de Namur, pp. 53-55.

Malison, J.A.; Kayes, T.B.; Best, C.D.; Amundson, C.H.; Wentworth, B.C., 1986: Sexual differentiation and use of hormones to contro sex in yellow perch (Perca flavescens). Can. J. Fish. Aquat. Sci. 43, 229-242.

Malison, J.A.; Procarione, L.S.; Held, J.A.; Kayes, T.B.; Amundson, C.H., 1993: The influence of triploïdy and heat and hydrostatic pressure on the growth and reproductive development of juvenile yellow perch (Perca flavescens). Aquaculture 116, 121-133.

Mélard, C.; Kestemont, P., 1994: Diversification de la pisciculture en Région Wallonne; mise au point de l'élevage intensif de nouvelles espèces de consommation et de repeuplement: cyprinidés et percidés. Rapport de recherches à la Région Wallonne, Université de Liège, Facultés Universitaires Notre Dame de la Paix à Namur, mars 1994, $68 \mathrm{pp}$.

Mélard, C.; Kestemont, P., 1995: Diversification de la pisciculture en Région Wallonne; mise au point de l'élevage intensif de cyprinidés et percidés. Rapport de recherches à la Région Wallonne, Université de Liège, Facultés Universitaires Notre Dame de la Paix à Namur, avril $1995,58 \mathrm{pp}$

Mélard, C.; Baras, E.; Desprez, D.; Philippart, J.C.; Kestemont, P., 1994: Intensive culture of perch (Perca fluviatilis). First results on the effects of stocking density on growth and survival of larvae and juveniles. In: Measures for Success. EAS Spec. Publ. 21, Oostende, Belgium, pp. 206-207.

Mélard, C.; Grignard, J.C.; Desprez, D.; Philippart, J.C.; Kestemont, P., 1995a: Intensive culture of European Perch (Perca fluviatilis) in warm water effluents. In: Abstract Book Percis II, Second International Percid Fish Symposium. Abstract book, FGFRI, Helsinki, Finland, p. 53.

Mélard, C.; Baras, E.; Kestemont, P., 1995b: Preliminary results of European perch (Perca fluviatilis) intensive rearing trials: Effect of temperature and size grading on growth. Bull. Fr. Pêch. Pisc. 336, 19-27.

Mélard, C.; Baras, E.; Mary, L.; Kestemont, P., 1996: Relationships between stocking density, growth, cannibalism and survival rate in intensively cultured larvae and juveniles of perch (Perca fluviatilis). Ann. Zool. Fennici, 9, 33, 3-4, (in press).

Setälä, J.; Käyhkö, A.; Muje, P.; Salmi, P., 1995: The commercial utilization of small perch (Perca fluviatilis) in Finnish inland fisheries. In: Abstract Book Percis II, Second International Percid Fish Symposium. Abstract book, FGFRI, Helsinki, Finland, p. 70.

Tamazouzt, L.; Capdeville, B.; Fontaine, P.; Terver, D.; georges, A., 1993: Growth of perch (Perca fluviatilis) fed on a formulated diet reared in two cultured systems: closed circuit and floating cages. In: From Discovery to Commercialisation. EAS Spec. Publ., Oostende, Belgium, p. 272.

Tamazouzt, L.; Dubois, J.P.; Fontaine, P., 1994: Production et marché actuels de la perche (Perca fluviatilis) en Europe. Pisc. Franç. 114, 4-8.

Thorpe, J., 1977: Synopsis of biological data on the perch, Perca fluviatilis (Linnaeus, 1758) and Perca flavescens (Mitchill, 1814). FAO Fish. Synop. $\mathrm{N}^{\circ} 113$, vii, 138 p.

Authors' address: Laboratory of Fish Demography and Aqualculture, University of Liège, 10 Chemin de la Justice, B-4500 Tihange, Belgium 